\title{
Case study of permeability-reducing admixture use in anti- flotation slabs: building in Brasilia, Brazil
}

\author{
E. F. Silva ${ }^{1}$ - M. Moreira ${ }^{1}$ M. A. R Manzano $^{1} \cdot$ R. Blanco $^{2}$
}

Received: 30 June 2016/ Accepted: 22 October 2016/Published online: 17 December 2016

(C) Springer International Publishing Switzerland 2016

\begin{abstract}
The time that the concrete must keep its properties, known as service life, it is an important design parameter for the performance of concrete structures. A porous concrete has a higher degree of water and aggressive permeability agents, which can cause deterioration of the reinforcement for mechanisms such as corrosion, besides not ensuring the watertightness, for example, on slabs under negative hydrostatic pressure (anti-flotation slabs). This type of slab has been used for the purpose of enabling or facilitating constructive actions associated with structures located beneath the groundwater table. There are several advantages of this type of construction: reduction of environmental impacts as it prevents the installation of permanent submersible pump systems, which reduces the use of electricity; nonoccurrence of settlement caused by the lowering of the groundwater table, which extends to the nearby areas of the construction site; and less impact to the groundwater table, which has serious consequences on the availability of this resource in urban areas. This paper presents a case study on the concreting of an anti-flotation slab, $30 \mathrm{~cm}$ thick and volume of $750 \mathrm{~m}^{3}$, of reinforced concrete, in a mixed use residential/commercial building, located in Northwest Sector, Brasilia, Brazil. To ensure the watertightness of this anti-flotation slab, a permeabilityreducing admixture was used to prevent hydrostatic condition, known for its ability to promote the sealing of cracks up to $0.4 \mathrm{~mm}$ by self-healing phenomenon. The results showed that both the composition of the concrete
\end{abstract}

\footnotetext{
E. F. Silva

eugenia@unb.br

1 Department of Civil and Environmental Engineering, Faculty of Technology, University of Brasília (UnB), Brasília, Brazil

2 Construtora Habitar, Brasília, Brazil
}

(containing permeability-reducing admixture) and setting the appropriate constructive strategies were essential to ensure an intact and tight structure.

Keywords Self-healing Concrete · Admixtures · Permeability $\cdot$ Anti-flotation slab

\section{Introduction}

Several factors may affect the performance of a structure in regards to the impermeability over time. These factors, whether internal or external, such as attacks by sulfates and chlorides, surface wear, carbonation, weathering, alkaliaggregate reactions and even the performing procedures that disagree with the rules can lead to concrete pathologies as corrosion on the reinforcement bar structure, reduction of steel sections, cold joints and cracks, which reduces the service life of the structure, and consequently compromising the durability of the system.

With the ABNT NBR 6118: 2014 publication [1] it was announced the use of high strength concrete up to $90 \mathrm{MPa}$. This type of concrete provides great advantages, both economic and structural such as high strength to mechanical stresses, low porosity and permeability, and therefore a lower cost for maintenance. On the other hand, there are disadvantages such as a high degree of autogenous and thermal shrinkage when the heat dissipation conditions are not favorable. The volumetric variations for being critical in the early age increase the concrete's vulnerability that may cause cracks, deteriorating the mechanical properties, and/or durability of the concrete.

In addition, to design constructions capable of promoting an efficient barrier to water entry, such as dams, water treatment stations, water storage tanks, anti-flotation slabs, 
is necessary the use of resistant materials and low permeability. The biggest problem in the use of concrete in these types of construction is related to the difficulty of obtaining the final watertightness structure, which depends on both the material and the consistent processing with good enforcement practices, so that no formation of cracks or cold joints are foreseen, through which percolation of water can occur [2].

Various techniques have been developed to reduce the permeability of concrete giving the possibility of higher mechanical strength and durability [3]. To reduce the passage of fluid through the concrete an improvement is needed in the cement paste which involves the aggregates from the use of low water/cement ratio, the larger cement consumption and use of water reducing chemical admixture (superplasticizers). Furthermore, there is technological choice of using some specific chemical admixture to reduce permeability, acting through the integral crystallization within the capillaries pores and the concrete micro cracks.

Concrete is a material susceptible to cracking and greater the opening of the crack, larger the impairment of the durability of the structure, requiring repair. The intentional introduction of self-healing properties in the concrete, from the use of permeability-reducing admixtures (PRA) could be beneficial. It represents a saving of direct costs, both in products and workforce, and an indirect cost because these structures would spend less time out of service during the service repairs [4].

Different approaches have been developed for the study of the concrete that has the capacity of self-repairing their own cracks. A self-healing concrete is a composite capable of self-healing when damaged, without external intervention, inspired by biological systems such as human skin, which is able to regenerate [5]. According to the ACI 212.3R -10 [6] report on chemical admixtures, to reduce the permeability can be classified as: permeability-reducing admixtures exposed to non-hydrostatic conditions (PRAN) and permeability-reducing admixtures exposed to hydrostatic conditions (PRAH).

The PRAHs are synthetic cementitious materials classified as hydrophilic waterproofing, reducing the permeability from the increase of resistance to water penetration under pressure in the concrete, providing an increase of the structure durability [6]. The PRAH's are crystalline admixtures compound by active ingredients which in the free presence of water, react with the cement paste products such as calcium hydroxide, aluminum, metal oxides and water; and form an insoluble crystalline structure within the pores and micro cracks of up to $0.4 \mathrm{~mm}$ [7].

Self-healing concrete was used in several projects in Brazil, such as in the anti-floating slab of the Museum of Image and Sound (M.I.S) [2], in Rio de Janeiro. This is a slab of $1 \mathrm{~m}$ thick; with a volume of $1200 \mathrm{~m}^{3}$ of watertight concrete with water/binder ratio of 0.35 (Fig. 1a). For the fluid coverage of the Rio Art Museum (M.A.R) [8], in Rio de Janeiro, was also specified a self-healing concrete to a volume of $320 \mathrm{~m}^{3}$ and with a water/binder ratio of 0.45 (Fig. 1b). The slab construction in the basement of the condominium Adelaide, located in Salvador, $630 \mathrm{~m}^{3}$ of self-healing concrete was used with water/binder ratio around 0.47 (Fig. 1c). This type of concrete was also used in the reform of the Governador Magalhães Pinto Stadium complex, in Belo Horizonte (Fig. 1d).

\section{Project data and procedures adopted in the slab construction}

\subsection{Project basic data}

The building of Soul Housing \& Shopping, the subject of this article, is located in the Northwest Sector of BrasíliaFederal District, and considered the first ecological neighborhood planned in Brazil. It consists of 20 blocks, 11 plots of land, 220 residential buildings, 140 commercial buildings, and an exclusive area for a bike path. Being the latter housing sector expected to be built in Brasilia, the city was declared as a historical and cultural heritage of humanity. The entire set was supported by sustainable solutions. The project is a vertical construction consisted of nine floors and 3 underground sub-levels, to be used as a parking place, 1 ground floor and 1 mezzanine consisted of shops, three residential floors of apartments and 1 penthouse.

Because of its ecological neighborhood, the construction arranged in the Northwest Sector has to follow the procedures contained in the sustainability manual, named Green Manual, developed by TERRACAP-Development agency of the Federal District [12]. During the executive planning it was necessary to implement the Environmental Management Plan, involving activities for erosion and sedimentation control, solid waste management and pollution control of the construction site.

The biggest challenge of the project's execution was the construction of an underground anti-floating slab. It was necessary to ensure the watertightness of the slab adopting a waterproofing system with the use of PRAH due to the upwelling of the groundwater table, and by specification of the project that did not allow the use of water pumps. This type of concrete was also used in the blocks and on the foundation walls.

The watertight anti-floating slab in reinforced concrete has an area of $2,500 \mathrm{~m}^{2}, 30 \mathrm{~cm}$ thick, with a total volume of $750 \mathrm{~m}^{3}$. Due to the total volume of concrete used in the slab construction, $3,000 \mathrm{~kg}$ of PRAH was applied with a $72,208 \mathrm{~kg}$ of reinforcing steel. The total concreting of the 

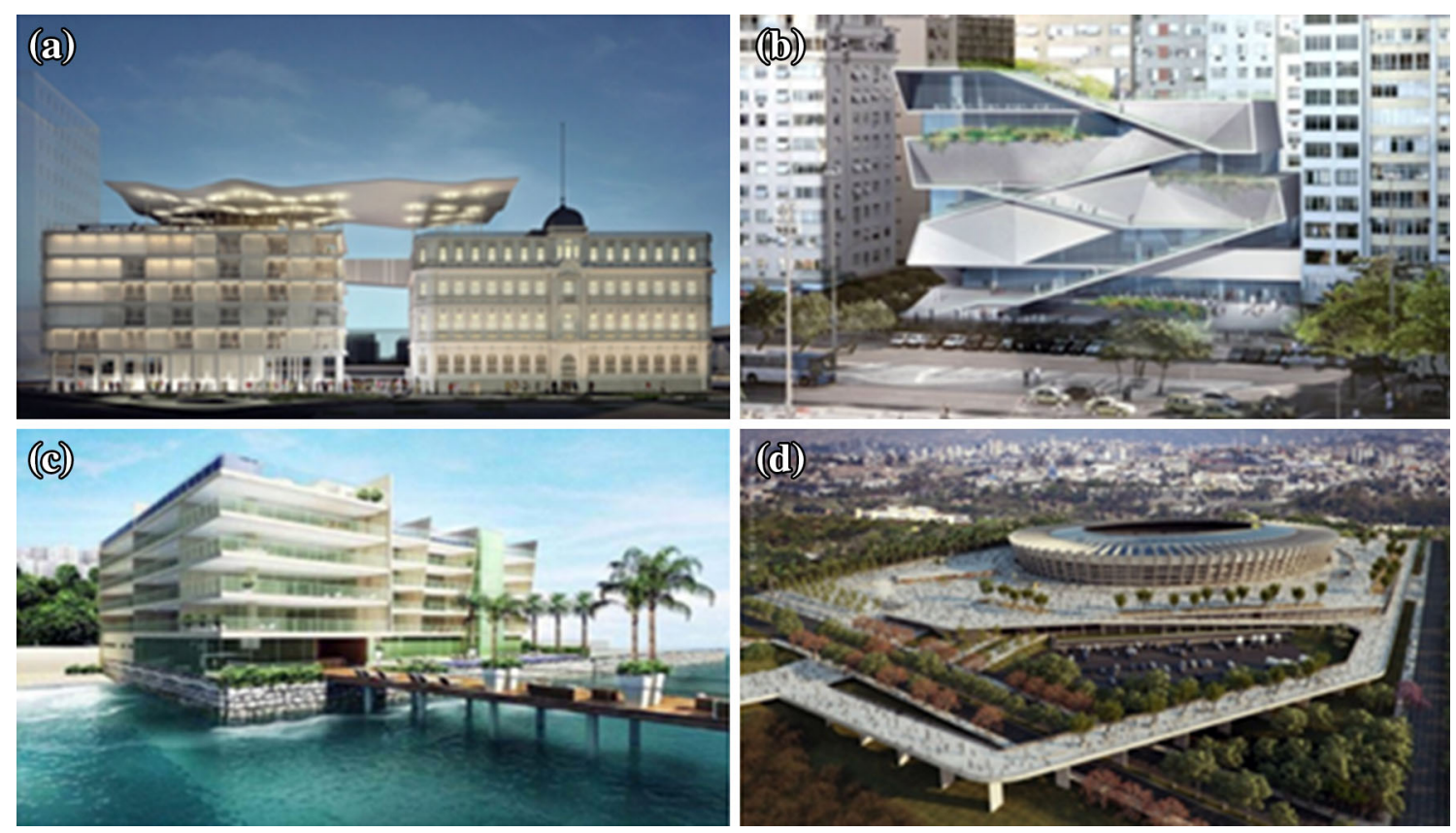

Fig. 1 Construction where self-healing concrete was used: a Art Museum of Rio de Janeiro, RJ [9]; b Museum of Image and Sound, RJ [10]; c Condominium Adelaide, BA [3] and d Mineirão Stadium Complex [11]

anti-flotation slab was performed in 3 stages with an interval of one month between them, with the execution of each stage lasting about $4 \mathrm{~h}$ and the cold joint treatment was provided.

\subsection{Mix design}

The construction of underground anti-flotation slabs present challenges during the execution phase in respect of waterproofing the concrete. By being subjected to a constant hydrostatic pressure of water, a less porous concrete production is necessary to reduce the incidence of water penetration from some phenomena such as water absorption by capillarity and water permeability (due to hydrostatic pressure, through the pores or micro cracks). As high durability is a requirement for this type of structure, the mix design of the concrete was performed by following the specifications of the structural project and the technologist's recommendations:

- $\mathrm{f}_{\mathrm{ck}, 28} \geq 35 \mathrm{MPa}$;

- water/cement ratio $\leq 0,60$ : according to the aggressiveness class;

- slump of $20 \pm 2 \mathrm{~cm}$ : to increase productivity in the discharge and placing;

- minimum cement content $=350 \mathrm{~kg} / \mathrm{m}^{3}$;

- minimum elasticity modulus at the formwork striking time-E > $21 \mathrm{GPa}$;

- placing temperature of concrete $\leq 30{ }^{\circ} \mathrm{C}$;
- evaporation rate $\leq 0.5 \mathrm{~kg} / \mathrm{m}^{2}$ of exposed concrete surface per hour;

- addition PRAH: self-healing process for the cracks;

- use of polypropylene fibers.

The PRAH was measured according to the manufacturer's instructions at a ratio of $0.8 \%$ by cement content mass, and added during the concrete production, in the concrete mixer. The concrete was produced according to the ABNT NBR 12655: 2015 [13] and ABNT NBR 7212: 2012 [14] requirements. The mix design used in the antiflotation slab is shown in Table 1.

The superplasticizer admixture was used to improve the workability of concrete, providing good pump flow properties, according to initial slump test $(20 \pm 2 \mathrm{~cm})$. The Project was located in a residential area, and there was a restriction for the circulation of the truck mixers until $10 \mathrm{pm}$ in the neighborhood. Thus, the specified slump for the concrete allowed greater flexibility during concrete placing, started at $4 \mathrm{pm}$, in order to reduce the potential thermal shrinkage in all 3 stages.

The treatment of each concrete joint occurred by the installation of a flexible hydro expansive tape (Penebar SW 55-B), hydrophilic material that expands in a controlled and slow manner, and when exposed to moisture causes a sealing between the concrete joint. The tape was adhered on the old concrete interface through an acrylic polymer emulsion (Penebar Primer), and a PRAH paste was applied to ensure an adhesion bridge between the new concrete and the old concrete. 
Table 1 Concrete mix proportion used in the antiflotation slab

\begin{tabular}{ll}
\hline Materials & Constituent $\mathrm{kg} / \mathrm{m}^{3}$ \\
\hline CP III- 40 RS Brazilian-type Cement & 380.00 \\
Natural sand (MF = 1.07) & 384.00 \\
Artificial sand (MF = 2.95) & 415.00 \\
Limestone coarse aggregate (maximum size of $9.5 \mathrm{~mm})$ & 205.00 \\
Limestone coarse aggregate (maximum size of $19 \mathrm{~mm})$ & 818.00 \\
Mixing water & 170.00 \\
Polyfunctional additive (829 SPX) & 1.91 \\
Superplasticizer additive (Tecflow 50 N) & 1.51 \\
Addition PRAH & 3.04 \\
Polypropylene fibers & 0.45 \\
\hline
\end{tabular}

\subsection{Manufacture of concrete}

A ready-mixed concrete was used for the anti-flotation slab with high quality control. The maximum volume of concrete at each stage, was approximately $270 \mathrm{~m}^{3}$ (27 truck mixers were used in each stage, with $10 \mathrm{~m}^{3}$ of concrete in each). The average time for receiving and discharging of each truck mixers was approximately $15 \mathrm{~min}, 750 \mathrm{~m}^{3}$ of concrete was placed in about $12 \mathrm{~h}$, with an effective manufacture of $67.5 \mathrm{~m}^{3} / \mathrm{h}$ in each stage.

It is worth mentioning that of each truck mixer was verified the placing temperature of concrete and the concrete slump in site, immediately before placing into the formwork. The determination of the temperature of the concrete was performed with a digital thermometer rod (Fig. 2a).

In order to avoid thermal cracking, the concrete placing was carried out at night to reduce the temperature peaks throughout the day; in addition the truck mixer drums were externally cooled with water. A useful reduction in the placing temperature of concrete was achieved simply and cheaply by shading the aggregate stockpiles from the direct rays of the sun, and by controlling sprinkling of the stockpiles. The cement used had a high content of granulated blast furnace slag (35-70\% of mass).
After casting, the measurement of the temperature was performed using thermocouple probes, placed inside the concrete for subsequent monitoring in situ (Fig. 2b, c). This procedure provided the actual temperature of the concrete, differently from the surface measurements that can be influenced by the external environment. A Data Logger was used for the automatic acquisition of the temperature data, collected every $60 \mathrm{~min}$, in order to evaluate the progress in the first $24 \mathrm{~h}$.

During concrete placing, two piston pumps were used (one as standby) due to the difficult access to slab, located at $9.8 \mathrm{~m}$ below the surface level (Fig. 3a, b).

The operations of placing and compacting were carried out almost simultaneously. The concrete was pumped vertically in a uniform layer, $30 \mathrm{~cm}$ thick, and the compacting was carried out using four internal vibrators according to ABNT NBR 14931: 2004 [15]. As the concrete joints were the major points of attention to ensure the watertightness of the structure, joint sealing tape or hydro expansive tape was installed minutes before the start of the next stage of placing, being applied in the middle of the previous slab depth, and throughout its length.

The curing of the concrete was carefully planned to obtain a good quality concrete beginning during the early stages of concrete hardening with spraying of water on the
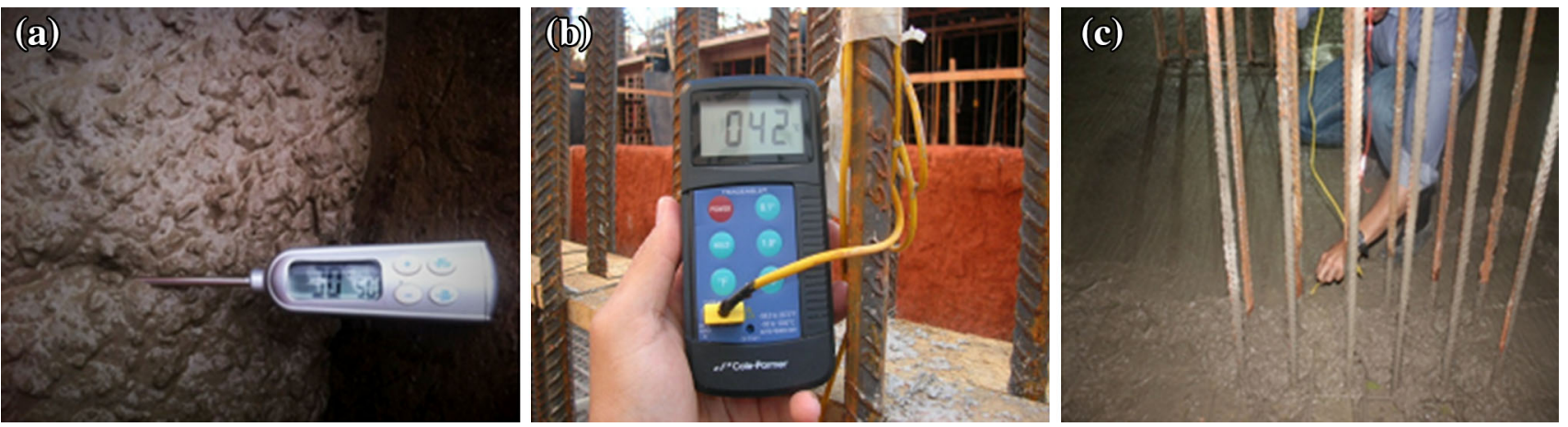

Fig. 2 Temperature measurements in concrete: $\mathbf{a}$ in truck mixers, from a digital thermometer rod; $\mathbf{b}$ at the placing, with the thermocouple bead probes and $\mathbf{c}$ installation of the thermocouple bead probe wires inside the concrete 

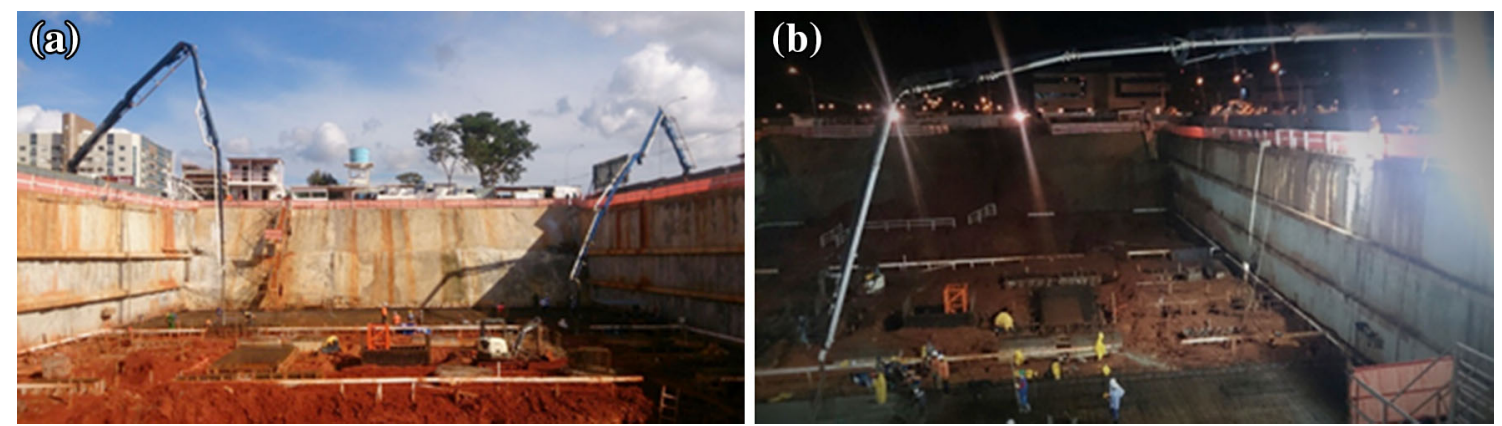

Fig. 3 Concrete placing at the 1 st stage of the slab, from the far-reaching pipes
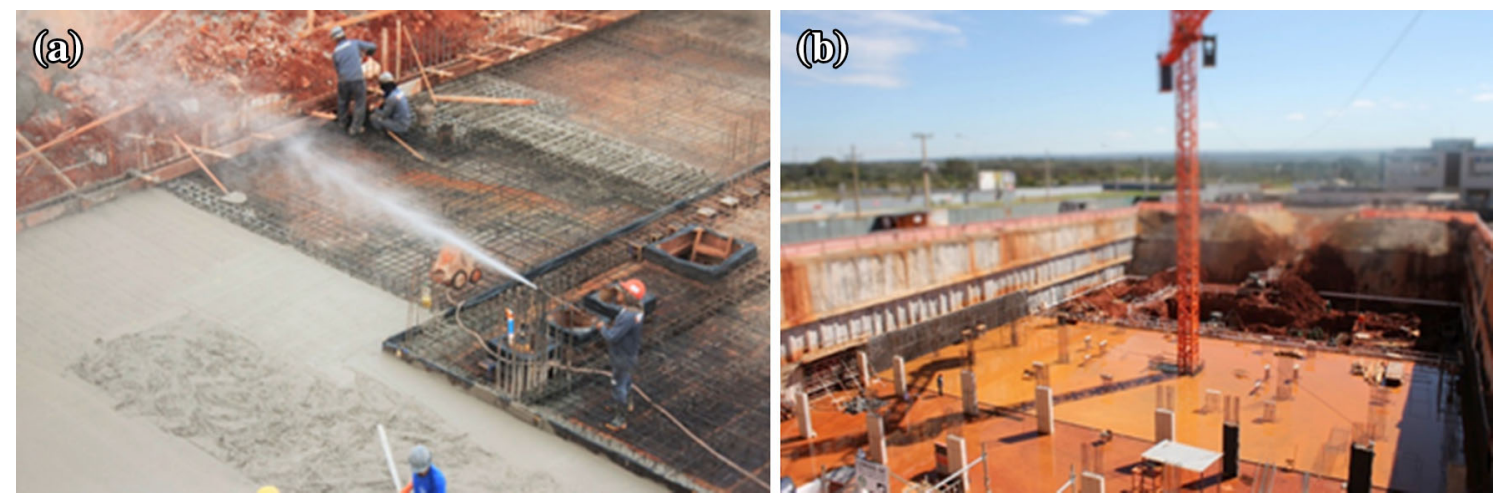

Fig. 4 Details of the type curing: a moist curing by spraying water on the concrete, $\mathbf{b}$ moist curing through water

concrete surface, as shown in Fig. 4a. This wet mist was important to prevent the loss of water from the concrete to the environment, minimizing the risk of cracking. After concrete hardening the moist curing was started by damming a water depth of $5 \mathrm{~cm}$ height for at least 7 days (Fig. 4b).

During the placing of anti-floating slabs under pressure, some relevant procedures were used, and which are worth mentioning, such as:

- To ensure the integrity and positioning of the lower slab reinforcing steel, it was prepared with a thin concrete mix, fck $=15 \mathrm{MPa}$, with coarse aggregate, with maximum aggregate size- $-D_{\text {Máx }}=19 \mathrm{~mm}$, slump of $10 \pm 2 \mathrm{~cm}$, carried out before the structural concrete placing (Fig. 5a);

- The hydro expansive tape (Penebar SW55-B) was installed over the length of the concreted layer interface just before the concreting (Fig. 5b);

- To prevent displacement of the hydro expansive tape during the concrete placing it was used a primer based on acrylic emulsion (Penebar Primer) which improves adhesion between the tape and the concrete surface (Fig. 5c);

- The connection between the concrete of different ages, a paste with self-healing additive (trace with volume of water 1: $2.5 \mathrm{PRAH}$ ) was applied. This procedure was performed within 20 min before the placing of the new concrete (Fig. 5d);

- During casting, to ensure a humidity above $50 \%$, spraying water was performed on the working area;

- Verification of the self-healing concrete, in relation to the presence of PRAH from the tracker in its mix, due to the sensitivity to UV rays makes the bleeding water with the color "yellow-fluorescent";

- During the arrival of each batch truck to site, a quality control of concrete was carried out from a company certified by Inmetro.

\section{Results}

\subsection{Quality control of concrete}

Acceptance and conformity of the concrete was carried out following the requirements of the standard ABNT NBR 12655: 2015 [13]. The property of the fresh concrete was checked in each batch by the consistency measured with slump test, and all the values obtained in this experiment were within the specification of $20 \pm 2 \mathrm{~cm}$.

For acceptance and compliance with specified concrete strength, 4 cylindrical specimens of $100 \times 200 \mathrm{~mm}$ of each truck mixer were molded, following the standard 

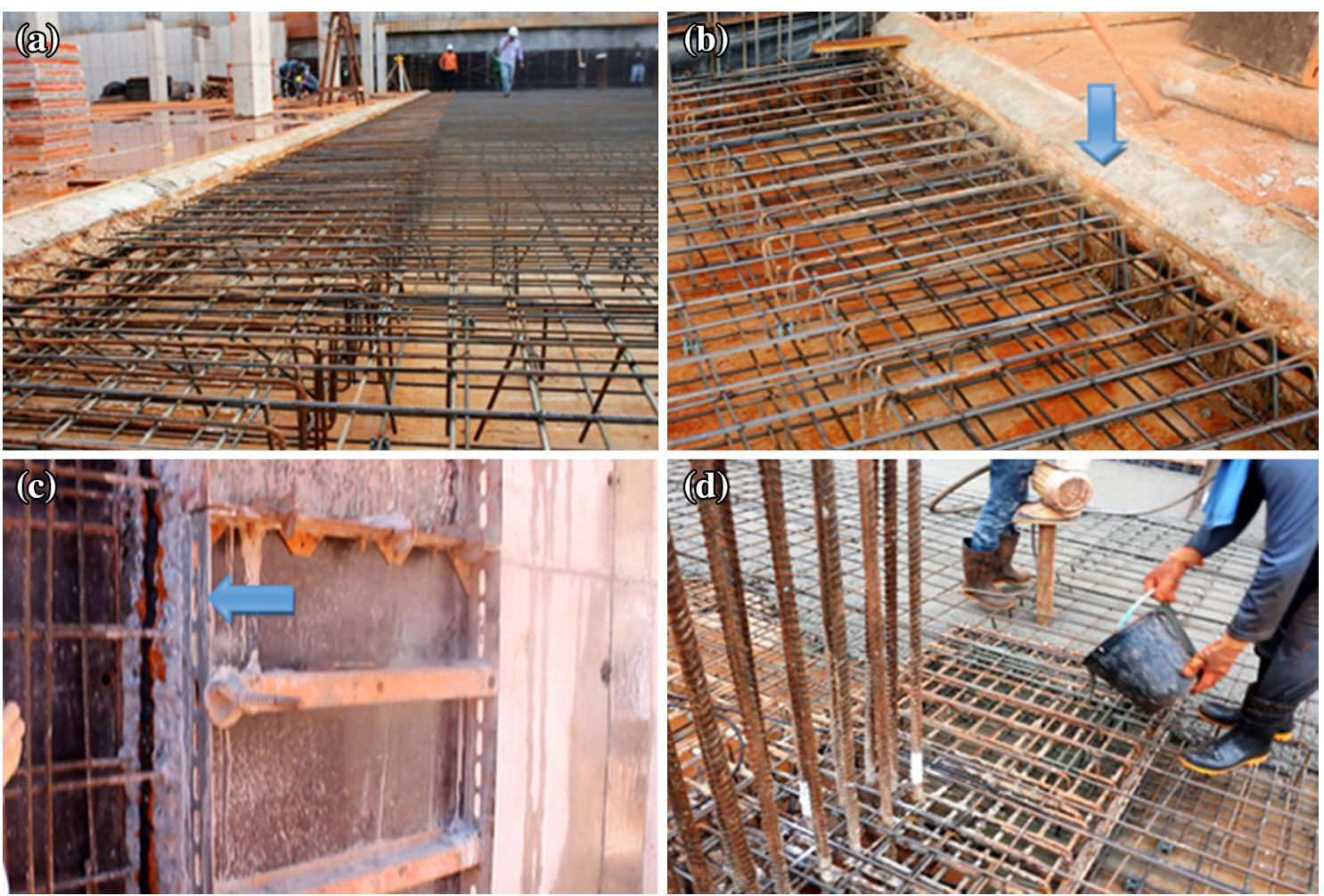

Fig. 5 Detailed procedure considered relevant during the concrete placing of the anti-floating slab

Fig. 6 Compressive strength at 28 days

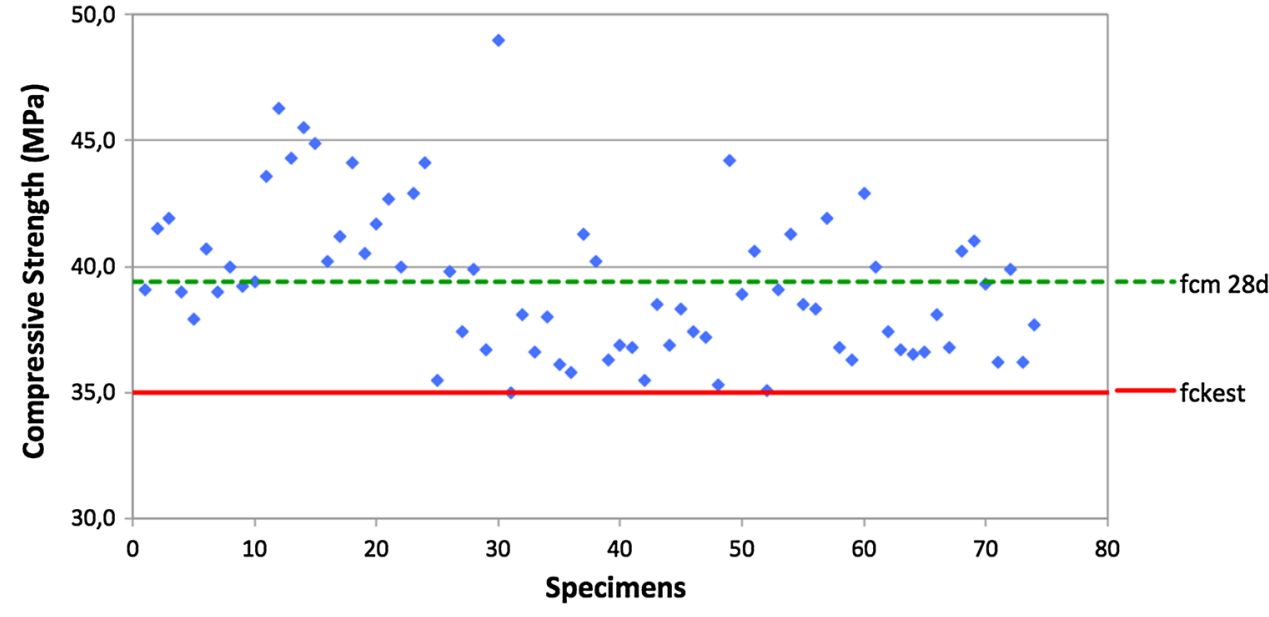

\subsection{Temperature control}

According to the technical specifications of the designer and the technologist's recommendations, the temperature control was done properly. Initially, for the acceptance of the concrete, the temperature was measured by using the digital thermometer rod as showed in Fig. 3a. The temperature values collected from the concrete mixer trucks in the three stages of the concrete placing are shown in Fig. 7.

Only in the first casting, the pumpability temperature exceeded $30^{\circ} \mathrm{C}$, but the maximum value reached was 
$31{ }^{\circ} \mathrm{C}$, which did not affect the operations of concrete placing. The trend of temperature decreases was observed over time for each stage. This behavior was expected as it was settled in the recommendations that the concrete was poured after $4 \mathrm{pm}$, avoiding thermal cracking [18].

Subsequently, the evolution of temperature over time was monitored from the installation of two thermocouple bead probes (Data Logger) in the concrete at each stage. These sensors permitted the development evaluation of the temperature inside the concrete during the first $24 \mathrm{~h}$, as well as identifying its maximum value. Figure 8 shows the evolution of the temperature of first stage -2 thermocouple bead probes.

The first stage was the one with the highest temperature peak among the three stages of concreting. In this case, the maximum concrete temperature was $41.8^{\circ} \mathrm{C}$ that was measured after $19 \mathrm{~h}$ from the concrete placing. This value recorded by the sensors was less than the stipulated limit $\left(60{ }^{\circ} \mathrm{C}\right)$ to prevent potential problems by thermal cracking. Therefore, it can be concluded that all strategies used for the quality control were satisfactory.

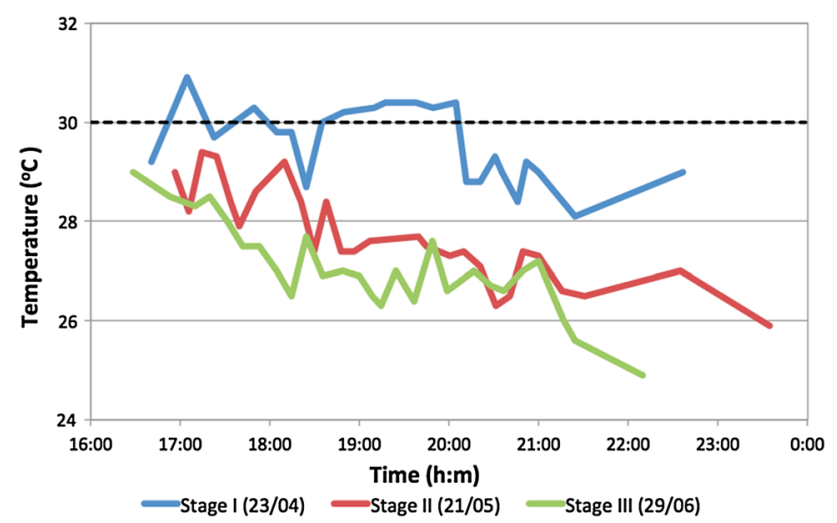

Fig. 7 Temperature values in the concrete placing at the construction site by stages

\subsection{Watertightness}

The watertightness of a concrete structure can be understood as the ability of this structure not permitting percolation of liquids, by any of the walls, joints or slabs that confine them [2]. In order to evaluate this property, a pressurized water penetration test was performed besides a visual inspection throughout the anti-flotation slab stages. It was determined that there was no cracking of thermal origin or shrinkage, even in more critical areas as the water tank, which was located on the lower level of the construction site, -3,68 $\mathrm{m}$ below the anti-flotation slab superior level. Moreover, both the walls of the project and the slab did not show leakage or water percolation problems, as shown in Fig. 9.

To determine the concrete strength to water penetration under pressure, three cylindrical specimens with $150 \mathrm{~mm} \times 300 \mathrm{~mm}$ were molded according to the standard ABNT NBR 10787: 2011 [20]. After the period of curing for 28 days, the specimens were sawn in half, using the bottom for testing. Since the area exposed to water pressure was scarified in order to make it rough, eliminating the surface film, which presents low permeability. Subsequently, the specimens were air-dried for $24 \mathrm{~h}$ before the beginning of the test and then placed in the equipment. The test started with the entry of the water and the application stages of pressure for $96 \mathrm{~h}$, after this period the specimens were removed from the equipment, dried the surface and split in half, orthogonally to the face where pressure was exerted, adopting a similar method to that performed to determine the tensile strength by diametrical compression following the parameters of ABNT NBR 7222: 2010 [21]. The results of the height average maximum of the water penetration for each specimen are shown in Table 2.

Several studies have reported a reduction of permeability due to the addition of the PRAH, when compared to
Fig. 8 Temperature evolution of the of first stage concrete layer over time [19]

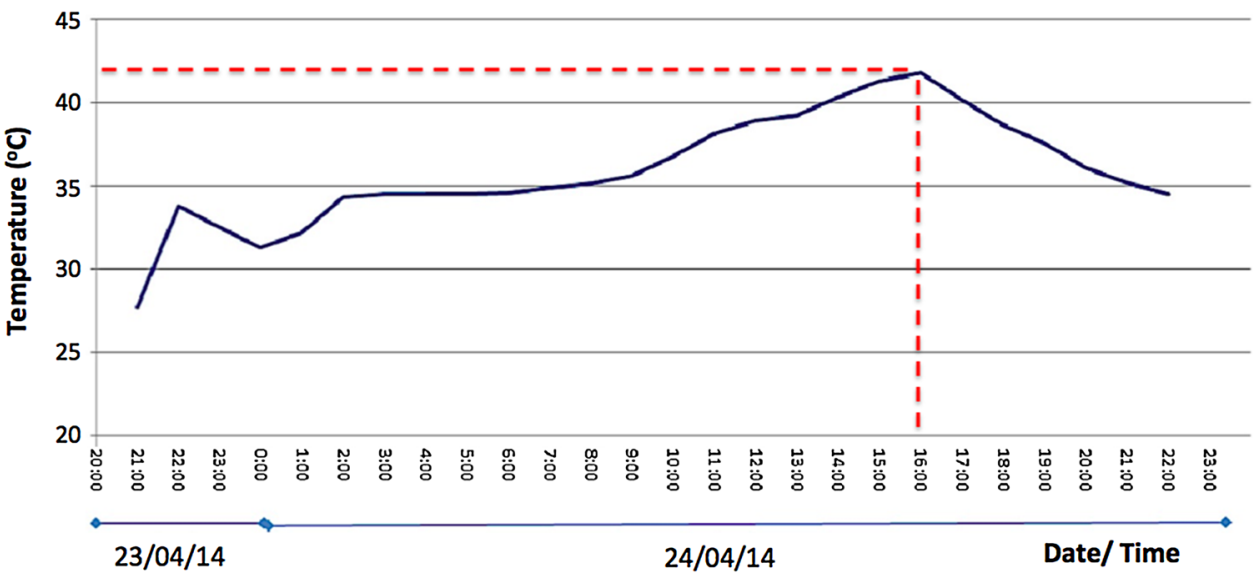




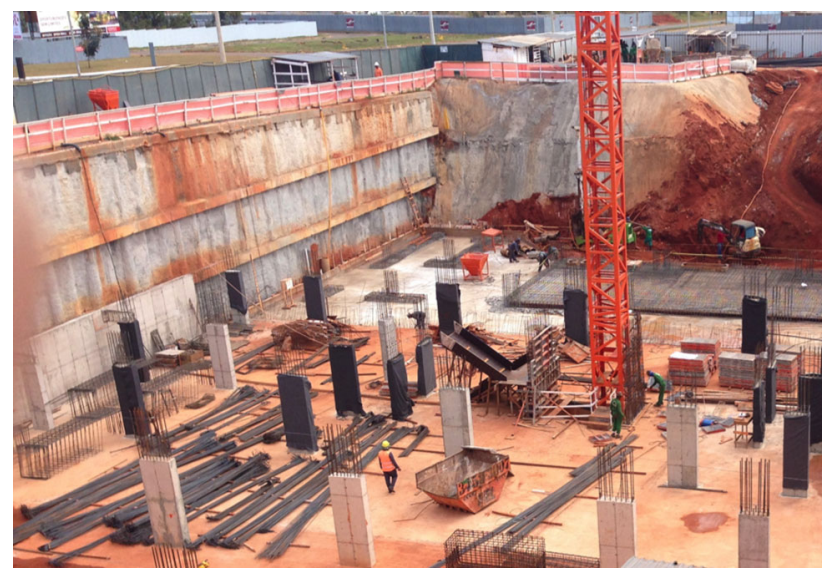

Fig. 9 Anti-flotation slab and side walls

Table 2 Results of the maximum height average of water penetration

\begin{tabular}{llll}
\hline $\mathrm{N}^{\circ}$ CPs & $\begin{array}{l}\text { Dimensions of } \\
\text { specimens }(\mathrm{mm})\end{array}$ & $\begin{array}{l}\text { Height average of the } \\
\text { water penetration }(\mathrm{mm})\end{array}$ \\
\cline { 2 - 3 } & Width $(\mathrm{mm})$ & Height $(\mathrm{mm})$ & \\
\hline $\mathrm{CP} 1$ & 150 & 150 & 8 \\
$\mathrm{CP} 2$ & 150 & 150 & 7 \\
$\mathrm{CP} 3$ & 150 & 151 & 6 \\
\hline
\end{tabular}

a reference mixture, including the paper of Takagi [4], using $2.5 \%$ of PRAH content and $\mathrm{w} / \mathrm{c}$ ratio $=0.6$, when it was verified a reduction of $12 \%$ permeability in samples with PRAH and a water penetration height average equal to $20 \mathrm{~mm}$. Ourives et al. [3] evaluated the performance of the self-healing concrete as the penetration of water under pressure, they concluded that the addition of $1 \%$ of PRAH in the concrete with w/c ratio $=0.47$, decreased on average $57 \%$ of the maximum water penetration depth in relation to the concrete without PRAH, reaching an average height of around $21 \mathrm{~mm}$. In tests performed by the Institute for Technological Research [22] in concrete with cement CPIII-40 and adding $2 \%$ of PRAH, it was observed that there was a reduction of water penetration under pressure $(0,7 \mathrm{MPa}$ for $72 \mathrm{~h})$, up to approximately $70 \%$ compared to the specific reference. Flores et al. [19] by analyzing the effect of self-healing in samples of cracked concrete, in relation to $\mathrm{w} / \mathrm{c}=0.45$ and cracks on the order from 0.0 to $0.3 \mathrm{~mm}$, stored under water immersion, it was concluded that the addition of $4 \%$ PRAH considerably decreased the permeability, and the presence of water is essential for the mechanism of the self-healing concrete.

In research conducted by Ferrara et al., [23] the efficacy of fiber-reinforced concrete (FRC) and crystal mixtures were evaluated, commercially available, on the self-healing capacity of cementitious materials. It was concluded that concrete mixtures containing made-to-measure admixtures of PRAH and fibers, when used properly, can contribute to the significant increase in water penetration resistance besides increasing the self-healing capacity of cracks in cement based materials.

When comparing the values of water penetration under pressure to the anti-flotation concrete slab with other authors, it can be observed the positive effect of the PRAH addition regarding to the permeability of concrete. The results obtained in the pressurized water penetration test were lower than those presented by Takagi [4] and Ourives et al. [3], which was expected since the ability of selfhealing also depends on the w/c ratio used, the type of cement composition, the mineral admixtures ratio, beyond the level of PRAH and the addition of fibers.

Also according to Takagi [4], it is recommended to use PRAH in compound dosages of additional mineral, such as fly ashes, the silica fume and blast-furnace slag, with levels ranging from 25 to $70 \%$ of content and ductile type of synthetic fibers. The PRAH has been effective in improving the durability of the anti-floating slab under pressure concrete, and the results of the pressurized water penetration test complemented the evaluation of the slab watertightness, since there were no leakage problems or percolation of water in the concrete.

\section{Final considerations}

Through the project specifications compliance as well as the technologist's recommendations on: the mix design, the addition of permeability-reducing admixture, the technological control activities and construction procedures; it was possible to achieve an integrated and tight structural element (no thermal or shrinkage cracking). It was not need to perform any other waterproofing procedure after the curing of the concrete, reducing maintenance costs showing that the use of PRAH is a viable alternative in construction with high requirements for watertightness and durability.

It is considered that procedures carried out throughout the paper are in accordance with the prescribed standards and can be considered as good practice for similar projects in the future. In terms of penetration of water under pressure, the beneficial effect of crystallization waterproofing additives to the action of water was confirmed.

Eventually, further investigation is necessary about the crystal formation phenomena formed by PRAH in the cracks through microstructural characterization such as SEM, DRX, infrared spectroscopy and differential thermogravimetric analysis. Thus, this may provide a better understanding of the self-healing mechanism of this material, in order to use it more safely, properly and reliably. 
Acknowledgements The authors thank Habitar Real Estate Development Construction Company for allowing the development of this work, for their support and cooperation in providing information. The High Education Personnel Improvement Coordination (CAPES) for financial support, the Penetron Brazil Ltda, and the structural engineers Renato Cortopassi (Kali Engeneering Company) and Ruy Barretto Junior (RDB Engeneering Company).

\section{References}

1. The Brazilian Association of Technical Norms (2014) NBR 6118: Design of concrete structures: procedure. Rio de Janeiro, p 221

2. Britez, C.; Helene, P., Bueno, S.; Pacheco, J. Watertightness of slabs of underpressure. Caso MIS-RJ. Rev. IBRACON Estrut. Mater. [online]. 2014, vol.7, n.6, pp. 913-921. ISSN 1983-4195

3. Ourives CN, Araújo N, Freire PS (2013) Case study: the waterproofing of the subsoil of the condominium Adelaide. $13^{\circ} \mathrm{Sim}-$ pósio Brasileiro de Impermeabilização. São Paulo, p 11

4. Takagi, E. M. self-healing concrete with cement, Brazilians of slag from blast furnace enabled by catalytic converter lens. 2013. $130 \mathrm{f}$. Master's thesis in engineering of Airport Infrastructure Instituto Tecnológico de Aeronáutica, São José dos Campos

5. Rilem (2013) Self-healing phenomena in cement-based materials. Springer, Heidelberg, v.11

6. American Concrete Institute (2010) ACI 212.3R-10: Report on Chemical Admixtures for Concrete. USA

7. Lema, D. et al, durability of structures by waterproofing by crystallization of concrete. Rev. Concrete and buildings. [online]. 2015, vol.77, pp. 94-102. ISSN 1809-7197

8. Almeida, I. R. de. A onda de concreto que flutua no M.A.R. Rev. CONCRETO e Construções. [online]. 2013, vol.72, pp. 100-110. ISSN 1809-7197

9. Duvivier JG, Sanson M (2013). In: Art of travel: MAR. Museu de Arte do Rio. 2013. http://www.artoftravel.com.br/web/dt_portfo lio/mar-museu-de-arte-do-rio/. Accessed 4 feb 2016

10. Techne.Pini. In: Entenda a execução da estrutura do Museu da Imagem e do Som, no Rio de Janeiro. 2014. http://techne.pini. com.br/engenharia-civil/206/artigo311463-3.aspx. Accessed 4 feb 2016
11. Minas arena. In:Estádio Governador Magalhães Pinto. http://www. minasarena.com.br/mineirao/esplanada/. Accessed 4 feb 2016

12. Terracap, Companhia Imobiliária de Brasília. Manual Verde Noroeste. Plano de Gestão Ambiental de Implantação. Manual Ambiental de Construção (PGAI). Licença de Instalação. Brasília, 2009

13. Associação brasileira de normas técnicas (2012) NBR 12655: concreto de cimento Portland - Preparo, controle e recebimento: Procedimento. Rio de Janeiro, p 18

14. Associação brasileira de normas técnicas (2012) NBR 7212: Execução de concreto dosado em central:Procedimento. Rio de Janeiro, p 16

15. Associação brasileira de normas técnicas (2004) NBR 14931: Execução de estruturas de concreto: Procedimento. Rio de Janeiro, p 53

16. Associação brasileira de normas técnicas (2015) NBR 5738: Concreto-Procedimento para moldagem e cura de corpos de prova. Rio de Janeiro, p 9

17. Associação brasileira de normas técnicas (2007) NBR 5739: Concreto-Ensaios de compressão de corpos-de-prova cilíndricos. Rio de Janeiro, p 9

18. Engenharia MM (2015) Relatório Técnico Medição de Temperatura Da Laje De Subpressão. Brasília-DF

19. Flores MR, Moscato S, Serna P, Ferrara L (2015) Self-healing capability of concrete with crystalline admixtures in different environments. Constr Build Mater 86:1-11

20. Associação brasileira de normas técnicas. NBR 10787: Concreto Endurecido - Determinação da Penetração de água sob pressão. Rio de Janeiro, 2011. 6p

21. Associação brasileira de normas técnicas (2011) NBR 7222: Concreto Endurecido-NBR 7222—Determinação da resistência à tração por compressão diametral de corpos de prova cilíndricos, Rio de Janeiro, p 7

22. Instituto de pesquisas tecnológicas do estado de São Paulo (IPT) (2007) Relatório de Ensaio n ${ }^{\circ}$ 97383-205, São Paulo, p 7

23. Ferrara L, Albertini I, Gettu R, Krelani V, Moscato S, Pirritano F, Flores MR, ROS PS, Theeda SM (2015) Self-healing of cement based materials engineered through 1 crystalline admixtures: experimental results from a multinational university network. In: International Concrete Abstracts, v.305, pp 13.1-13.10 